\title{
Bioinformatics Analysis to Reveal Potential Differentially Expressed Long Non-Coding RNAs and Genes Associated with Tumour Metastasis in Lung Adenocarcinoma [Corrigendum]
}

\author{
Yao X, Zhang H, Tang S, Zheng X, Jiang L. Onco Targets \\ Ther. 2020;13:3197-3207.
}

The authors of this paper have advised that the affiliation list on page 3197 is incorrect. The correct author and affiliation list is as follows:

\section{Xiaojun Yao ${ }^{1,2}$ \\ Hongwei Zhang ${ }^{2}$ \\ Shujun Tang ${ }^{2}$ \\ Xinglong Zheng ${ }^{2}$ \\ Liangshuang Jiang'}

'Department of Thoracic Surgery, The Public Health Clinical Center of Chengdu, Chengdu, People's Republic of China; ${ }^{2}$ Department of Thoracic Surgery, Meishan Cancer Hospital, Meishan, People's Republic of China

The authors apologize for this error.

\section{Publish your work in this journal}

OncoTargets and Therapy is an international, peer-reviewed, open access journal focusing on the pathological basis of all cancers, potential targets for therapy and treatment protocols employed to improve the management of cancer patients. The journal also focuses on the impact of management programs and new therapeutic agents and protocols on patient perspectives such as quality of life, adherence and satisfaction. The manuscript management system is completely online and includes a very quick and fair peer-review system, which is all easy to use. Visit http://www.dovepress.com/ testimonials.php to read real quotes from published authors. 